\title{
PENGEMBANGAN KOMIK DIGITAL CHLOROPHYL SEBAGAI MEDIA PEMBELAJARAN PEDULI LINGKUNGAN SISWA SMA
}

\author{
BACHTIAR ADI SAPUTRA \\ SMA Muhammadiyah 1 Taman \\ e-mail: bachtiar.smamita19@gmail.com
}

\begin{abstract}
ABSTRAK
Hilangnya rasa tanggung jawab yang dimiliki para pelajar terhadap menjaga dan melestarikan alam juga menjadi dampak buruk dari kemajuan yang terjadi pada era masa kini. Oleh karena itu, peneliti bernisiatif untuk mengembangkan media pembelajaran berbasis komik digital chlorophyl yang valid dan praktis untuk digunakan dalam menanamkan kepedulian terhadap lingkungan sekitar. Metode yang digunakan dalam penelitian ini adalah penelitian mengembangkan dengan prosedur ADDIE (Analyze, Design, Development, Implementation, and Evaluation). Pengembangan komik digital Chlorophyl ini terdiri atas 12 halaman mulai dari halaman pembuka tentang perkenalana tokoh utama, permasalahan hingga solusi yang bisa dilakukan untuk menjaga lingkungan hidup. Komik digital Chlorophyl dapat dikatakan valid dengan rata-rata yaitu 3,58 dan memiliki kriteria baik sehingga dapat digunakan di lapangan dengan sedikit revisi yang telah disesuaikan dengan saran dari para ahli. Selain itu berdasarkan masukan dari validator dengan beberapa catatan perbaikan dan penilaian angket respon siswa terhadap komik digital chlorophyl dinyatakan sangat praktis dengan respon positif sebanyak 80,59\%. Kesimpulan yang didapatkan adalah komik digital chlorophyl yang dikembangkan dikatakan valid dengan nilai 3,5 dan dinyatakan sangat praktis dengan respon positif sebanyak $80,59 \%$.
\end{abstract}

Kata Kunci: komik digital, pengembangan media, peduli lingkungan

\section{ABSTRACT}

The loss of a sense of responsibility that students have towards protecting and preserving nature is also a bad impact of the progress that has occurred in the present era. Therefore, the researchers took the initiative to develop a valid and practical "chlorophyll" digital comic-based learning media to be used in instilling concern for the surrounding environment. The method used in this research is developing research using ADDIE (Analyze, Design, Development, Implementation, and Evaluation) procedures. The development of this digital Chlorophyl comic consists of 12 pages starting from the opening page about the introduction of the main character, problems to solutions that can be done to protect the environment. Chlorophyl digital comics can be said to be valid with an average of 3.58 and have good criteria so that they can be used in the field with a few revisions that have been adapted to suggestions from experts. In addition, based on input from the validator with several notes of improvement and the assessment of student responses to chlorophyll digital comics, it was stated that it was very practical with a positive response of $80.59 \%$. The conclusion obtained is that the digital chlorophyll comic that was developed is said to be valid with a value of 3.5 and stated to be very practical with a positive response of $80.59 \%$.

Keywords: digital comics, media development, care for the environment

\section{PENDAHULUAN}

Permasalahan pandemi Corona Virus Disease (Covid-19) yang menyerang sistem pernafasan pada tahun 2020 setiap hari semakin meninggi sehingga ditetapkan sebagai pandemi oleh WHO. Virus Covid telah mengubah dunia termasuk Indonesia salah satunya dalam bidang pendidikan. Sekolah yang tadinya bisa dilakukan secara tatap muka di kelas menggunakan papan untuk mengajar sekarang harus berubah menjadi pembelajaran yang menggunakan jaringan sehingga harus dilaksanakan secara daring atau virtual (Gusty, et al., 2020). 
Pembelajaran secara daring dari rumah membuat para pelajar menjadi lebih fokus pada gadget mereka masing-masing sehinga mengurangi kepedulain pada lingkungan yang ada di sekitar mereka. Berbagai tugas dan kegiatan pembelajaran yang dilakukan secara daring banyak menyita waktu dan tenaga mereka sehingga membuat mereka acuh terhadap permasalahan yang ada pada konsisi lingkungan. Hal tersebut didukung oleh penelitian dari Masitoh (2006) bahwa penyebab ganguan kesehatan dan kebersihan lingkungan adalah tingkat kepedulian masyarakat terhadap alam sekitar sangat menurun.

Hilangnya rasa tanggung jawab yang dimiliki para pelajar terhadap menjaga dan melestarikan alam juga menjadi dampak buruk dari kemajuan yang terjadi pada era masa kini. Kerusakan pada alam semakin banyak terjadi seperti lingkungan yang kumuh, banjir, kekeringan, kebakaran hutan, dan masih banyak lagi bencana alam terjadi dan membuat alam tak lagi sehat. Berbagai hal tersebut disebabkan oleh perilaku manusia dalam berkehidupan di era modern ini. Selain itu juga masih terdapat banyak aktivitas yang merusak lingkungan seperti eksploitasi sumberdaya alam (hutan, perikanan, sungai), semakin banyaknya aktivitas yang menyebabkan polusi udara, air, dan daratan (Soeprobowati, 2020).

Oleh karena itu perlu adanya penanaman kepedulian terhadap lingkungan meskipun kita sedang dalam kondisi pandemi yang menyulitkan siswa untuk belajar langsung di alam sekitar. Dunia pendidikan perlu untuk terus menempa siswa untuk memiliki sikap ilmiah serta meningkatkan kesadaran guna memelihara dan melestarikan lingkungan serta sumber daya alam meskipun hanya bisa memanfaatkan pembelajaran secara digital (Saputra \& Nurdiansyah, 2020). Hal tersebut berkaitan erat dengan kebutuhan di era digital ini terutama terkait kecakapan dalam memecahkan permasalahan kehidupan serta berperan serta dalam berkontribusi terhadap pelestarian lingkungan (Ardiansyah \& Arda, 2020).

Salah komponen penting yang dibutuhkan dalam menghadapi tantangan pembelajaran di masa pandemi adalah kreativitas pendidik dalam menggunakan bahan ajar yang menarik dalam proses pembelajaran. Hal tersebut perlu dupayakan supaya peserta didik nyaman dalam belajadan mampu mencapai tujuan pembelajaran yang diharapkan (Metro, 2017). Hasil penelitian yang relevan dalam penanaman peduli lingkungan di masa pandemi adalah pegembangan bahan ajar berupa e-modul berbasis karakter peduli lingkungan di masa pandemi covid-19, dimana hasil penelitian tersebut dinilai layak oleh para ahli, praktis untuk digunakan serta mendapatkan respon yang positif dari peserta didik (Marisa, Yulianti, \& Hakim, 2020).

Berdasarkan penelitian lapangan yang dilakukan di SMA Muhamamdiyah 1 Taman, peneliti banyak mendapati pendidik yang menggunakan metode pembelajaran yang monoton dalam penyampaian materi yaitu membuat grup/kelompok hanya memanfaatkan aplikasi whatsapp ataupun presentasi melalui zoom/google meet. Selain itu adanya penugasan berupa pengerjaan soal yang dikumpulkan melalui foto ataupun video dirasa semakin membebani siswa sehingga membuat mereka semakin acuh dengan kepedulian pada lingkungan sekitarnya. Oleh karena itu perlu adanya upaya dari guru untuk mengembangkan media yang mudah dipahami oleh siswa dalam upaya untuk ikut serta menjaga dan memperbaiki lingkungan yang ada di sekitarnya (Setyowati \& Widiyatmoko, 2013).

Berkaitan dengan hal tersebut peneliti berinisiatif untuk memanfaatkan media berupa komik digital menjadi sebuah media pembelajaran yang membahas tentang permasalahan lingkungan sekitar serta upaya untuk ikut serta melestarikannya. Hal tersebut merupakan alternatif dari peneliti untuk memanfaatkan kemajuan teknologi berupa komik digital melalui aplikasi canva yang bisa diakses secara online yang memuat materi tentang perubahan lingkungan dan upaya untuk mengatasi permasalahan lingkungan.

\section{METODE PENELITIAN}

Metode penelitina yang digunakan dalam penelitian ini adalah penelitian pengembangan (Research and Development) untuk menghasilkan produk tertentu, dan dapat menghasilkan produk digunakan penelitian yang bersifat analisis kebutuhan dan kurikulum (Sugiyono, 2016). Prosedur pengembangan yang digunakan adalah model pengembangan 
ADDIE yang terdiri dari 5 tahapan, yaitu Analyze, Design, Development, Implementation, dan Evaluation. Namun dalam penelitian ini, peneliti membatasi model pengembangan hanya sampai dengan tahapan Development (Sari, 2010).

Prosedur penelitian yang dilakukan terdiri dari beberapa tahap penelitian diantaranya analisa tentang keadaan yang tengah ramai dan terjadi. Selanjutnya Pada tahap analyze, peneliti melakukan identifikasi masalah dan menentukan kebutuhan dasar. Pada tahap analisis juga dilakukan proses pengumpulan informasi berupa beberapa data terkait materi, sikap, dan karakter peserta didik terhadap suatu pembelajaran materi tertentu (Kustianingsari \& Dewi). Adapun hasil setelah mengidentifikasi masalah dasar yakni peneliti menemukan 79 persen dari 215 siswa kelas X SMA Muhammadiyah 1 Taman masih masih seringkali tidak peduli dengan lingkungan alam sekitar.

Berdasarkan hasil analisis selanjutnya, maka dilakukan tahap perancangan bahan atau design. Pada tahap ini, dimulai dengan membuat rancangan awal berupa sketsa untuk memudahkan dalam membuat komik digital. Hasil dari tahap ini berupa kerangka komik yang akan dikembangkan lebih lanjut. Kemudian peneliti merancang lembar validasi (Utama, p. 04).

Tahap selanjutnya ialah tahap pengembangan, dimana kami mendesain komik yang memiliki 8 halaman yang memuat halaman sampul, isi, dan penutup. Di bagian pengembangan, kami mengembangkan desain dengan mengunggah komik tersebut dalam bentuk flipbuilder. Komik yang telah diunggah, diimplementasikan kepada siswa-siswi kelas satu SMA Muhammadiyah 1 Taman. Tahap terakhir adalah evaluasi terhadap komik yang telah dibuat. Selain itu dalam tahap pengembangan, juga dilakukan analisa kevalidan serta kepraktisan komik digital berupa instrumen yang telah dirancang sebelumnya. Kemudian dilakukan evaluasi formatif, yaitu validasi oleh tim ahli untuk mengetahui kevalidan isi serta desain pada komik, setelah itu diperoleh saran sebelum diterapkan kepada peserta didik.

Teknik pengumpulan data yang digunakan yakni teknik angket yang diberikan kepada beberapa validator ahli materi dan ahli desain yang berupa lembar validasi tentang pengembangan komik digital chlorophyl. Adapun komponen yang divalidasi yaitu visual, materi, pembelajaran, media, manfaat, dan bahasa. Komik digital yang telah divalidasi oleh validator digunakan sebagai bahan pertimbangan dalam merevisi komik digital tersebut (Hakim, 2017).

Teknik analisis data yang digunakan peneliti adalah analisis kevalidan dan kepraktisan. Langkah-langkah yang digunakan dalam menganalisis kevalidan dan kepraktisan sebagai berikut; (Cahyana, 2019) 1) Memasukkan data ke dalam tabel-tabel untuk dianalisis, 2) Mencari rata-rata tiap kriteria dari semua validator, 3) mencari rata-rata tiap aspek, 4) mencari rata-rata total validator, 5) menentukan kevalidan komik digital dari hasil rata-rata total validitas dengan mencocokan pada kategori kevalidan media pembelajaran dengan kategori kevalidan pada tabel 1 .

Tabel 1. Kategori Kevalidan Media Pembelajaran

\begin{tabular}{c|c}
\hline Interval Skor & Tingkat Kevalidan \\
\hline $4 \leq R T V \leq 5$ & Sangat Valid \\
$3 \leq R T V<4$ & Valid \\
$2 \leq R T V<3$ & Kurang Valid \\
$0 \leq R T V<2$ & Tidak Valid \\
\hline
\end{tabular}

Keterangan: $\mathrm{RTV}=$ rata-rata total hasil penilaian validator

Komik digital dikatakan valid jika rata-rata total hasil penilaian validator terhadap komik digital chlorophyl berada pada kategori "valid" atau "sangat valid". Apabila terdapat skor yang kurang valid atau tidak valid, akan digunakan sebagai masukan untuk merevisi komik digital chlorophyl. Perbaikan komik digital chlorophyl dilakukan sesuai masukan validator yang menguji.

Untuk mengetahui kepraktisan komik digital chlorophyl, terdapat empat kriteria penilaian umum dengan nilai kualitatif yang ditentukan oleh validator (Firdaus \& Julianto, 
2021). Komik digital chlorophyl dikatakan praktis jika para validator menyatakan bahwa komik digital chlorophyl tersebut dapat digunakan dengan sedikit revisi. Berikut adalah pernyataan umum validator tentang komik digital chlorophyl sesuai dengan kualitatif yang diberikan ditunjukkan pada tabel 2 .

Tabel 2. Kriteria Penilaian Umum Dengan Nilai Kualitatif

\begin{tabular}{l|c}
\hline \multicolumn{1}{c|}{ Keterangan } & Nilai Kuantitatif \\
\hline Dapat digunakan tanpa revisi & $\mathrm{A}$ \\
Dapat digunakan dengan sedikit revisi & $\mathrm{B}$ \\
Dapat digunakan dengan banyak revisi & $\mathrm{C}$ \\
\hline Tidak dapat digunakan & $\mathrm{D}$ \\
\hline
\end{tabular}

Selain itu kepraktisan juga dinilai dari angket respon siswa mengenai tampilan komik, penyajian materi, penggunaan bahasa yang mudah dipahami serta manfaat yang dirasakan oleh siswa setelah menggunakan Komik digital chlorophyl. Komik digital chlorophyl yang dikembangkan dinyatakan cukup praktis apabila mendapatkan persentase di atas $50 \%$ dan sangat praktis apabila mendapatkan respon positif di atas 75\% (Tabel 3).

Tabel 3. Kriteria Kepraktisan berdasarkan Angket Respon Siswa

\begin{tabular}{l|c}
\hline Keterangan & Persentase \\
\hline Sangat Praktis (Dapat digunakan tanpa revisi) & $75,01 \%-100 \%$ \\
Cukup Praktis (Dapat digunakan dengan sedikit revisi) & $50,01-75,00 \%$ \\
Kurang Praktis (Dapat digunakan dengan banyak revisi) & $25,01-50,00 \%$ \\
(Tidak Praktis) Tidak dapat digunakan & $<25,00 \%$ \\
\hline
\end{tabular}

Sumber : (Sugiyono, 2016)

\section{HASIL DAN PEMBAHASAN}

Pengembangan komik digital Chlorophyl ini terdiri atas 12 halaman mulai dari halaman pembuka tentang perkenalana tokoh utama, permasalahan hingga solusi yang bisa dilakukan untuk menjaga lingkungan hidup. Halaman pembuka terdiri dari halaman pertama hingga keempat, pada halaman pertama dan kedua bercerita tentang tokoh bernama Roe yaitu karbon jahat yang mencemari kota dengan udara tidak sehat yang dihasilkan dari asap pabrik dan asap kendaraan bermotor. Sedangkan pada halaman tiga dan empat menceritakan sisi lain kota yang terdapat tokoh yang bernama Chloe yaitu daun yang masih hidup diantara teman temannya yang sudah mati akibat menghirup udara tidak sehat yang dihasilkan oleh Roe.

Halaman isi terdiri dari halaman empat halaman,yang menceritakan bahwa kerusakan lingkungan disebabkan oleh manusia itu sendiri. Pada halaman lima dan enam bercerita tentang pabrik dan kendaraan bermotor yang dikendalikan oleh manusia yang mengakibatkan Roe atau karbon semakin banyak sehingga memperburuk keadaan lingkungan. Pada halaman tujuh dan delapan bercerita tentang Chloe yang akan menemui Roe namun di tengan perjalanan ia menangis karena menemukan tidak ada lagi temannya yang masih hidup karena penebangan pohon yang dilakukan oleh manusia.

Halaman penutup komik lingkungan hidup berisi tentang pesan moral yang bisa kita ambil untuk menjaga lingkungan bersama-sama yang berada pada halaman sembilan hingga dua belas. Halaman sembilan dan sepuluh menceritakan Chloe yang melanjutkan perjalanannya ke kota dan bertemu manusia yang memakai makser karena batuk akibat menghirup udara tidak sehat yang dihasilkan Roe, Chloe akhirnya mengajak manusia-manusia itu untuk menambah teman-teman Chloe serta membasmi Roe dengan cara menanam pohon. Pada halaman sebelas dan dua belas bercerita tentang manusia yang mulai mengajak manusia lain untuk menanam pohon kembali dan pada akhir cerita, Chloe bertemu dengan Roe yang sedang menangis karena teman-temannya sudah mati karena lingkungan yang dirusak oleh Roe telah kembali hijau 
Untuk menguji kevalidan media komik digital yang dikembangkan, peneliti melakukan uji validasi pada tiga validator dengan rincian dua ahli media dan satu ahli materi. Validasi yang dilakukan meliputi penilaian terhadap tampilan atau desain dari komik, materi yang dibahas yaitu permaslahan lingkungan, bahasa yang digunakan mudah dipahami serta ciri khas dari komik yang dikembangkan yaitu unsur penanaman kepedulian terhdap lingkungan sekitar. Rekapitulasi hasil validasi ahli terhadap komik digital yang dikembangkan dapat dilihat pada tabel 4.

Tabel 4. Rekapitulasi Hasil Validasi Komik Digital

\begin{tabular}{l|c|c|c|c|c|c}
\hline \multirow{2}{*}{ Aspek Yang Dinilai } & \multicolumn{3}{|c|}{ Validator } & Rata- & Keterangan & \multirow{2}{*}{ Kriteria } \\
\cline { 2 - 6 } & I & II & III & rata & Kalid & Baik \\
\hline Tampilan/Desain & 4 & 3 & 4 & 3,67 & Baik \\
Materi yang dibahas & 3 & 3 & 4 & 3,33 & Valid & Baik \\
Bahasa yang digunakan & 3 & 4 & 3 & 3,33 & Valid & Baik \\
Penanaman Peduli & 4 & 4 & 4 & 4 & Sangat Valid & $\begin{array}{c}\text { Sangat } \\
\text { Baik }\end{array}$ \\
\hline \multicolumn{1}{c}{ Lingkungan } & $\mathbf{3 , 5 0}$ & $\mathbf{3 , 5 0}$ & $\mathbf{3 , 7 5}$ & $\mathbf{3 , 5 8}$ & Valid & Baik \\
\hline
\end{tabular}

Komik digital Chlorophyl dapat dikatakan valid dengan rata-rata yaitu 3,58 dan memiliki kriteria baik sehingga dapat digunakan di lapangan dengan sedikit revisi yang telah disesuaikan dengan saran dari para ahli. Penilaian validator yang mendapatkan respon sangat positif adalah pada aspek penanaman karakter peduli lingkungan, dimana dalam hal ini peneliti menggambarkan untuk ikut serta menjaga lingkungan sekitar dari hal terkecil seperti menanam dan merawat pohon di sekitar rumah, mengurangi penggunaan sampah plastik, mendaur ulang sampah yang masih bisa digunakan. Hal tersebut sejalan dengan penelitian yang dilakukan oleh Setyowati \& Widiyatmoko (2013) bahwa perlu adanya peran aktif dari guru sebagai pendidik untuk mengembangkan media mampu menanamkan sikap kepedulian pada siswa dalam upaya untuk ikut serta menjaga dan memperbaiki lingkungan yang ada di sekitarnya.

Penilaian validator dari aspek tampilan/desain, materi yang dibahas dan bahsa yang dugunakan mendapatkan nilai 3,67 dan 3,33 yang dapat dinyatakan valid atau baik untuk bisa digunakan sebagai media pembelajaran bagi siswa SMA di masa pandemi. Hal ini juga didukung oleh penelitian Yani Pratiwi (2021) yang menyatakan bahwa pemanfaatan komik digital di masa pandemi dirasa akan memudahkan siswa untuk memahami materi dan tertarik untuk belajar dikarenakan adanya upaya untuk menikmati dan memahami gambar yang disajikan secara menyeluruh akan mampu membangun imajinasi siswa sehingga membuat siswa tidak bosan untuk belajar.

Berdasarkan catatan dan masukan dari validator dapat dianalisa bahwa komik digital chlorophyl dikatakan praktis dikarenakan para validator menyatakan bahwa komik digital chlorophyl tersebut dapat digunakan dengan sedikit revisi atau mendapat poin B. Saran untuk perbaikan komik digital chlorophyl yang dikembangkan tercantum pada tabel 5.

Tabel 5. Saran Validator terhadap Komik digital

\begin{tabular}{|c|c|c|}
\hline No. & Catatan & Revisi \\
\hline 1. & $\begin{array}{l}\text { Ada beberapa background yang terlihat } \\
\text { jenuh atau kurang menarik }\end{array}$ & $\begin{array}{l}\text { Background diganti dengan yang } \\
\text { lebih mendukung suasana }\end{array}$ \\
\hline 2. & $\begin{array}{l}\text { Ada beberapa kalimat di percakapan yang } \\
\text { kurang tepat }\end{array}$ & $\begin{array}{l}\text { Kalimat pada percakapan diperbaiki } \\
\text { dengan tepat }\end{array}$ \\
\hline 3. & $\begin{array}{l}\text { Pewarnaan pada beberapa karakter dan } \\
\text { gambar terlihat kurang menarik }\end{array}$ & $\begin{array}{l}\text { Pewarnaan pada karakter dan gambar } \\
\text { dibuat lebih menarik }\end{array}$ \\
\hline
\end{tabular}


Selain itu, peneliti juga menguji kepraktisan komik digital chlorophyl dari angket respon siswa sebanyak 24 siswa kelas xi sma muhamamdiyah 1 taman yang menilai tampilan komik, penyajian materi, penggunaan bahasa yang mudah dipahami serta manfaat yang dirasakan oleh siswa. Berdasarkan rekapitulasi hasil angket respon siswa terhadap komik digital chlorophyl yang dikembangkan mendapatkan respon positif sebanyak $80,59 \%$ sehingga dinyatakan sangat praktis untuk digunakan sebagai media pebelajaran penanaman peduli lingkungan pada siswa SMA. Didukung oleh penelitian dari Aneng Fitriya Astutik dkk (2021) bahwa kepraktisan produk komik digital sebagai penguatan karakter siswa dilihat dari hasil respon siswa dalam uji coba lapangan mendapatkan skor 85\% termasuk kategori sangat baik. Selian itu juga didukung oleh penelitian dari Eka Sulistyawati dkk (2021) bahwa hasil respon siswa terhadap media media pembelajaran berbasis STEM rumah hidrolik di tinjau dari hasil belajar dan respon mendapatkan respon $80,6 \%$ yang termasuk dalam kategori sangat baik.

\section{KESIMPULAN}

Kesimpulan yang didapatkan adalah komik digital chlorophyl yang dikembangkan dikatakan valid dengan nilai 3,5 yang terdiri dari bagian perkenalan tokoh, bagian gambaran permasalahan lingkungan dan pesan moral untuk menjaga lingkungan. Selain itu berdasarkan masukan dari validator dengan beberapa catatan perbaikan dan penilaian angket respon siswa terhadap komik digital chlorophyl dinyatakan sangat praktis dengan respon positif sebanyak $80,59 \%$.

\section{DAFTAR PUSTAKA}

Ardiansyah, A., \& Arda, A. (2020). Peran Orang Tua Dalam Proses Belajar Anak Di Masa Pandemi Covid-19 Dalam Menumbuhkan Sikap Ilmiah (Studi Kasus Pada Siswa Usia 10-12 Tahun Pada Mata Pelajaran IPA). Musawa: Journal For Gender Studies, 12(1), , 140-164.

Astutik, A. F., Suprijono, A., \& Rusijono. (2021). PENGEMBANGAN MEDIA KOMIK DIGITAL DALAM PEMBELAJARAN IPS SEBAGAI PENGUATAN KARAKTER PESERTA DIDIK KELAS V SDN GELURAN 1 TAMAN. JURNAL EDUCATION AND DEVELOPMENT, 9(3), 542-554.

Cahyana, D. I. (2019). Pengembangan Perangkat Pembelajaran Strategi Konflik Kognitif Teori Kwon untuk Melatihkan Kemampuan Pemecahan Masalah Matematika Siswa. 55-64.

Firdaus, A., \& Julianto. (2021). PENGEMBANGAN MEDIA KOMIK DIGITAL MATERI PERUBAHAN WUJUD BENDA IPA KELAS V SEKOLAH DASAR. pengembangan komik digital, 1347.

Gusty, S., Nurmiati, N., Muliana, M., Sulaiman, O. K., Ginantra, N. L., Manuhutu, M. A., \& Warella, S. Y. (2020). Belajar Mandiri: Pembelajaran Daring di Tengah Pandemi Covid-19. Yayasan Kita Menulis.

Hakim, A. F. (2017). Pengembangan Konik Digital sebagai Media Pembelajaran Alat - Alat Pembayaran Internasional pada Materi Perekonomian Terbuka. 47.

Kustianingsari, N., \& Dewi, U. (s.f.). Pengembangan Media Komik Digital pada Mata Pelajaran Bahasa Indonesian Tema Lingkungan Sahabat Kita Materi Teks Cerita Manusia dan Lingkungan untuk Siswa Kelas V SDN Putat Jaya III/379 Surabaya. 3.

Marisa, U., Yulianti, Y., \& Hakim, A. R. (2020). Pengembangan E-Modul Berbasis Karakter Peduli Lingkungan di Masa Pandemi Covid-19. Prosiding Seminar Nasional PGSD UNIKAMA. Vol. 4. No. 1.

Masitoh, D. (2006). Tingkat Kedisiplinan Masyarakat Dalam Menjaga Budaya Hidup Bersih Terhadap Lingkungannya, Studi Kasus Pada Masyarakat Banaran, Kelurahan Sekaran, Kecamatan Gunungpati Semarang. . Diss. Universitas Negeri Semarang. 
Metro, S. P. (2017). PENGEMBANGAN BAHAN AJARTEMATIK DALAM IMPLEMENTASI KURIKULUM 2013 KELAS 1 SEKOLAH DASAR. . 9(2), 9398.

Pratiwi, Y. (2021). PENGEMBANGAN BAHAN AJAR KOMIK DIGITAL BERBASIS KEARIFAN LOKAL KOTA PALEMBANG PADA PEMBELAJARAN TEMATIK KELAS III DI SEKOLAH DASAR NEGERI 104 PALEMBANG. PALEMBANG: Diss. UNIVERSITAS ISLAM NEGERI (UIN) RADEN FATAH PALEMBANG.

Saputra, B. A., \& Nurdiansyah, N. (2020). Penguatan Literasi Digital melalui Model Pengembangan Kurikulum SMA Islam Berbasis Media Digital di Era 4.0. ISLAMIKA, 2(1), , 36-45.

Sari, B. K. (2010). Desain Pembelajaran Model ADDIE dan Implementasinya dengan Teknik Jigsaw. 87.

Setyowati, R., \& Widiyatmoko, A. (2013). LINGKUNGAN TEMA POLUSI SEBAGAI BAHAN AJAR SISWA SMK N 11 SEMARANG.

Soeprobowati, D. (2020). Akhlak Siswa Terhadap Alam. Alprin.

Sugiyono. (2016). Metode Penelitian Kuantitatif, Kualitatif dan R\&D. Bandung: Alfabeta.

Sulistyawati, E., Faizah, L., Nisa, I., \& Putra, I. G. (2021). Pengembangan Media Pembelajaran Berbasis STEM Rumah Hidrolik Di Tinjau dari Hasil Belajar dan Respon Siswa Terhadap Matematika. Journal Focus Action of Research Mathematic (Factor M), $3(2), 12$.

Utama, S. (s.f.). PERANCANGAN KOMIK SEBAGAI MEDIA PEMBELAJARAN TENTANG PEMESANAN DAN PEMBUATAN KOMIK. 4. 